\title{
An Assessment Of Patterns Of Coauthorship For Academic Accountants Within Premier Journals Edited Outside The U.S.:
Evidence From 1995 - 2009
}

\author{
Ted D. Englebrecht, Ph.D., Louisiana Tech University, USA \\ Xiaoyan Chu, DBA, Nicholls State University, USA \\ Fred Coleman, CPA, Louisiana Tech University, USA \\ Rebecca Martin, DBA, CPA, Louisiana Tech University, USA
}

\begin{abstract}
Research in accounting indicates that accounting faculty publish less in their elite journals than marketing, management, and finance faculty publish in their respective elite journals (Swanson, 2004). This paper investigates co-authorship ratios for twelve premier non-U.S. edited accounting and finance journals over the fifteen year period from 1995 to 2009. Our results suggest that for the years considered, the aggregate co-authorship ratio for non-U.S. premier accounting journals has increased significantly. Also our findings indicate that the financial accounting specialization has the highest level of co-authorship. Additionally, the co-authorship ratio for Top 25 non-U.S. universities is not significantly different than that of lower ranked non-U.S. academic institutions. We also observe that co-authorship among non-U.S. researchers is lower than that of U.S. researchers. The findings of this study indicate that trends of increasing co-authorship among non-U.S. premier accounting journals are consistent with those of U.S. premier accounting journals.
\end{abstract}

Keywords: Co-authorship; non-U.S. Premier Journals; Academic Accountants; Top 25 non-U.S. Universities

\section{INTRODUCTION}

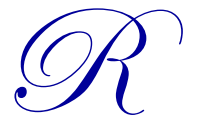

ecent research in accounting demonstrates that accounting faculty publish less in elite accounting journals than marketing, management, and finance faculty publish in their elite journals. Swanson (2004) notes that doctoral faculty in finance, marketing, and management publish 1.6 times more articles in their respective elite journals than accounting faculty. He also observes an increase in co-authorship in all four disciplines, which he concludes leads to greater competition and more difficulty publishing in elite journals overall compared to earlier time periods. It is salient for the academic accounting profession to specifically examine this co-authorship trend, given the greater difficulty of publication in elite accounting journals demonstrated by Swanson (2004). Englebrecht et al. (2008) empirically demonstrate that the co-authorship ratio among premier accounting journals has increased over time, regardless of the tier level or doctoral granting status of the researchers' institutions. This provides evidence to accounting researchers that in order to publish in such journals it is helpful to work with fellow researchers. However, in their research Swanson (2004) and Englebrecht et al. (2008) both utilize primarily U.S. edited premier accounting journals. Jones and Roberts (2005) note that accounting research regarding publication trends typically is missing an international focus. A separate study of co-authorship in non-U.S. elite journals is necessary for four reasons. First, since the Association to Advance Collegiate Schools of Business International (AACSB) is a multinational organization, publication trends around the world may be compared to those of the U.S. to assess world-wide developments. Second, the acceptability of coauthored manuscripts for tenure and promotion decisions may be different for non-U.S. academic institutions compared with that of U.S. academic institutions. Third, the international exchange of researchers among academic and non-academic organizations may 
influence the level of co-authorship. Last, prior research finds that non-U.S. edited journals have significantly fewer coauthored articles than the U.S. journals. Acedo et al. (2006) find that the European journals in management and organizational studies have significantly fewer coauthored articles than the U.S. journals. Furthermore, Jones and Roberts (2004) find that U.K. top accounting journal articles are more likely to be authored by single authors when compared with the U.S. top accounting journals. As a result, it is essential to investigate the co-authorship trend of accounting journals from an international perspective. Specifically, we extend prior research (Englebrecht et al., 2008; Swanson, 2004; Jones and Roberts, 2005; Beattie and Goodacre, 2004; Hyndman et al., 2006; Prather-Kinsey and Rueschhoff, 2004; Acedo et al., 2006) by examining the co-authorship ratios in twelve premier non-U.S. edited accounting and finance journals.

The remainder of this paper is organized as follows. First, an insight into the background literature is provided. This is followed by an explanation of the research design and data collection methodology. The next section presents an analysis of the results of the study. Last, we discuss our conclusions and limitations and provide suggestions for future research opportunities.

\section{BACKGROUND}

\section{Research Environment Factors}

Many studies have established that research productivity is valued higher than teaching or service in promotion and tenure decisions, especially at doctoral granting institutions (Henry and Burch, 1974; Campbell et al., 1983; Cargile and Bublitz, 1986; Schultz et al., 1989; Street et al., 1993; Englebrecht et al., 1994; Street and Baril, 1994; Hasselback et al., 2000; Chen et al., 2010). Limited research on publication patterns in European journals also demonstrates that publication requirements are increasing (Beattie and Goodacre, 2004; Hyndman et al., 2006). Additionally, researchers are often more motivated to publish in top journals for consideration in the promotion and tenure decision process (Ballas and Theoharakis, 2003; Swanson, 2004; Reinstein and Calderon, 2006; Attaway et al., 2008). Journal ranking lists are created to assess faculty members' scholarly contributions (Brown and Huefner, 1994; Reinstein and Calderon, 2006). Much of this emphasis results from the desire to comply with the accreditation standards of the AACSB (Yunker, 2000; Attaway et al., 2008).

Researchers have always competed for publication space in top accounting journals and the competition has become more intense over time. Collaborations are encouraged because it reduces the time spent by each individual, allows a blending of research skills, and enables researchers to reduce overall rejection risk (Swanson, 2004). Chung et al. (1992) examine the bibliometric distributions of research output in accounting literature from 1968 to 1988 . These authors note the difficulty of publications in accounting journals. That is, 57.7 percent of authors published only once during the time frame examined and only 9.8 percent of authors contributed more than five times. Other recent studies provide evidence that another contributing factor to coauthorship among accounting researchers is that publication space is even more limited in accounting journals than in other academic business disciplines (Buchheit et al., 2002; Swanson, 2004; Valacich et al., 2006). This contributes to the atmosphere of acute competition between researchers for the available space in these journals.

Innovations in technology allow researchers to communicate with coauthors at a greatly reduced cost. Hamermesh and Oster (2002) note that in the 1990s collaborative research between authors in different locations grew from five to fifteen percent. Technological improvements provide fast and accurate methods of sharing research ideas and data. Naturally, these innovations allow authors to increase their publication productivity outside the previous limitations of available resources at their affiliated universities.

\section{Theoretical Factors}

Barnett et al. (1988) have proposed several theoretical reasons for the increasing trend of co-authorship, which include the division of labor hypothesis, the opportunity cost of time hypothesis, quality hypothesis, and diversification hypothesis (Englebrecht et al., 2008). First, the division of labor hypothesis is based on Adam Smith's observations and theorizes that as a discipline's knowledge base grows over time, then, researchers are able to specialize more in certain areas. Given this specialization, researchers must work together to a greater degree to 
continue their research. Second, the opportunity cost of time hypothesis asserts that as publication requirements have increased for academics, there are less friendly reviewers of academic papers available. Thus, researchers require coauthors to ensure the appropriate level of stringent review of research papers. Third, the quality hypothesis provides that because of the increased demand on researchers to publish more papers for tenure and promotion requirements and limited available journal space, the quality of research papers must necessarily improve. If co-authorship improves the quality of papers, this provides an incentive to coauthor papers to ensure publication. Last, the diversification hypothesis argues that researchers spread their risk of rejection in the review process by utilizing different coauthors on academic papers. Furthermore, co-authorship allows researchers to increase their total number of papers submitted during a given time period. Also, it reduces the chances of a prolonged period whereby no papers are accepted in the journal review process.

\section{Analysis of Publication Research}

Recent research into accounting and other business faculty publication productivity reveals several trends. Swanson (2004) empirically studies the publication activity of accounting, finance, management, and marketing faculty from 1980 to 1999 and presents three important results. First, there are significant differences in the overall average publication activity between faculty members in each discipline - accounting, finance, management, and marketing. Second, the number of articles in all business disciplines has decreased because of increased quality required by reviewers. Third, Swanson observes an increasing trend of co-authorship within each business discipline, though marketing has a significantly higher rate of co-authorship. Englebrecht et al. (2008) find that trend in co-authorship in premier journals is increasing from 1979 to 2004. The majority of the accounting journals surveyed in Swanson (2004) and Englebrecht et al. (2008) are U.S. edited journals. The current study extends Swanson (2004) and Englebrecht et al.'s (2008) research by statistically examining the patterns of co-authorship among academic accountants within premier non-U.S. edited accounting journals.

Other research inquiries have explored the factors that motivate business faculty to conduct research. Levitan and Ray (1992) find that effective time management is the most important factor in accounting research productivity. Additionally, they observe that top researchers usually have a network of colleagues with which to interact and exchange ideas. Chen et al. (2006) use expectancy theory to describe factors which contribute to business faculty's motivation to conduct research. They find that extrinsic rewards (e.g., promotion and tenure) frequently motivate non-tenured faculty and intrinsic rewards (e.g., achieving recognition and obtaining respect from students) mostly motivate tenured faculty. In an extension of this research, Chen et al. (2010) note that faculty at doctoral granting institutions have significantly more publications in the top five accounting journals as compared to faculty at non-doctoral granting institutions. On the other hand, faculty at non-doctoral granting programs publish significantly more articles in non-top five journals in the study's most recent 24 months. Rutledge and Karim (2009) explicitly examine factors contributing to co-authorship for the most productive accounting researchers. Similar to conclusions drawn by Levitan and Ray (1992), Rutledge and Karim (2009) find evidence that prolific authors of accounting research produce longer articles and become more productive by working with other authors.

\section{International Trends}

Two studies investigate publishing patterns in accounting within the U.K. and Irish university sectors. The first study by Beattie and Goodacre (2004) examine trends in finance and accounting for both the U.K. and Irish communities. The authors analyze publishing patterns of accounting and finance faculty for the two-year period 1998 to 1999 using the British Accounting Review Research Register. The researchers find that 54 percent of all articles written by Irish and U.K. academic accountants are published in accounting and finance journals, with the remaining articles published in management, economics, sociology, education, and information technology journals. The authors note a statistically significant increase (44\% in contrast to $35 \%$ in 1991) in the number of academic staff publishing articles. Hyndman et al. (2006) examine publication patterns from eight Irish universities, and compare the differences in publication patterns using six two-year periods from 1988/89 to 2002/03. They find a meaningful increase in academic journal output from 0.16 in 1988/89 to 0.61 in 2002/03.

Beattie and Goodacre (2004) also examine co-authorship trends in their data. They find that 61 percent of all academic articles are coauthored, with an average of 1.93 authors per article. This average is significantly lower 
than the projected number of 2.4 authors per article based on Hasselback et al. (2000). Beattie and Goodacre (2004) suggest that fewer coauthors may be preferable in the U.K. relative to the U.S., but the authors are unable to explain this finding. While Beattie and Goodacre (2004)'s study is based on the U.K. and Irish accounting and finance academic community, the current study is based on the twelve non-U.S. edited accounting and finance journals. Also, in Beattie and Goodacre (2004), only 54.3\% of articles surveyed are from accounting and finance journals, while the current study focuses exclusively on accounting and finance journals. Another study compares the nationalities of authors' institutions in six elite U.K. and six elite U.S. accounting and finance journals from 1996 to 2000 (Jones and Roberts, 2005). They find that 117 out of 190 articles published in top U.S. journals by non-U.S. researchers have U.S. coauthors. Additionally, Jones and Roberts (2005) observe that, in accounting and finance $30.4 \%$ of U.K. joint publications are with foreign coauthors, $20.3 \%$ of U.S. joint publications are with foreign coauthors, and $63.6 \%$ of non-U.K./U.S. joint publications are with foreign coauthors. While Jones and Roberts (2005)'s study compares the articles by number of authors in top U.K. journals (60.45\% coauthored) and U.S. journals (66.63\% coauthored), the current study focuses on the co-authorship trend and include twelve non-U.S. edited accounting and finance journals (not only the top U.K. accounting journals ). The current study extends Beattie and Goodacre's (2004) and Jones and Roberts' (2005) research by examining a longer time period regarding co-authorship and statistically examining the factors that are significantly related to the increase in co-authorship.

Prather-Kinsey and Rueschhoff (2004) examine differences between U.S. and international accounting researchers by analyzing U.S. edited and non-U.S. edited accounting journals from 1981 to 2000 . While their research principally examines trends regarding international accounting research in these journals (i.e., the study of accounting for international transactions), Prather-Kinsey and Rueschhoff (2004) document an increase in foreign and domestic co-authorship. Particularly, the authors note that the rate of co-authorship is increasing faster for domestic and international authors versus the rate of single authored articles. This study extends their research by testing the significance of change in co-authorship from 1995 to 2009 of all accounting research topics (i.e., not limited to the international accounting research area). Additionally, we control for the number of manuscript pages and include supplementary factors such as category of journal, area of accounting specialization, university status, and researcher characteristics.

Acedo et al. (2006) conduct an exploratory analysis of co-authorship in management journals from 1980 to 2002. These authors use logistic regression and find that coauthored articles are significantly related to the number of pages per article and the date of publication. They note that European journals have significantly fewer coauthored articles. Our study also utilizes logistic regression to examine non-U.S. edited journals. Additionally, we not only analyze the relationship between co-authorship and article length, but also type of journal (accounting or finance), area of accounting specialization (financial, managerial, audit, tax or other), status level of authoraffiliated university (top tier non-U.S. university or other), and type of author (international academic, U.S. academic, and non-academic).

\section{HYPOTHESES}

Earlier research has presented evidence that co-authorship ratios are increasing in premier accounting journals. Englebrecht et al. (2008) address a void in the literature by statistically examining the long-term components of co-authorship by accounting researchers in premier journals. This current study extends that analysis by focusing on non-U.S. edited journals and comparing our results to those of Englebrecht et al. (2008). Thus, the following hypotheses (in null form) are tested using logistic regression:

H1: There is no difference in the co-authorship ratios of non-U.S. edited journals for the period 1995 to 2009.

H2: There is no difference in co-authorship ratios of articles published in premier accounting versus premier non-accounting non-U.S. edited journals for the period 1995-2009.

The first hypothesis tests whether or not there is a long-term increase in the co-authorship ratio. The second hypothesis examines whether there is a significant difference in the co-authorship ratios of articles appearing in premier accounting and non-accounting journals over the study period. As noted by Englebrecht et al. (2008), if significant positive differences appear, researchers may note this as indirect evidence that collaboration is helpful in 
order to publish in higher quality journals. Additionally, university administrators and faculty promotion and tenure committees will be able to better assess how the publication of collaborative articles by their faculty within each journal category compares to accepted trends.

H3: There is no difference in co-authorship ratios for premier non-U.S. edited journals amongst specialized areas of study within accounting (i.e., Financial, Audit, Managerial, and Other) for the period 1995- 2009.

This hypothesis attempts to detect significant differences in co-authorship ratios within areas of specialization over the study's sample period. There are two possible benefits to findings of significant differences in co-authorship ratios as indicated by Englebrecht $e t$ al. (2008). First, accounting researchers will better understand the amount of author collaboration within their specialization areas to meet the qualitative norms for publishing. Second, faculty tenure and promotion committees will be better informed when evaluating candidates within different accounting specializations.

H4: There is no difference in co-authorship ratios between articles published at top tier non-U.S. universities and non-top tier non-U.S. universities for the period 1995-2009.

The model to test this hypothesis uses the 2010 London Financial Times Global MBA Rankings to analyze potential effects of university tier rankings on co-authorship. ${ }^{1}$ This information should help academics and administrators determine if their assessment of coauthored work should change based upon the status level of their affiliated universities.

H5: There is no difference in co-authorship ratios between international academics and U.S. academics for the period 1995-2009.

This hypothesis compares the co-authorship ratios of international academic researchers with that of U.S. academic researchers over the time period studied.

\section{RESEARCH DESIGN}

\section{Sample Selection}

Because rewards such as tenure and promotion for accounting faculty are often determined based upon whether they have published in premier accounting or finance journals, this study conducts coauthorship analysis on established premier non-U.S. edited journals. Several criteria are used for journal selection. First, we include the two non-U.S. edited journals Accounting, Organizations, and Society and Journal of Business Finance and Accounting which are used in the analysis by Englebrecht $e t$ al. (2008), because these journals are listed in the top fifteen journals from prior accounting journal ranking research (e.g., Hull and Wright, 1990; Zeff, 1996; Lowe \& Locke, 2002; Herron \& Hall, 2004).

Second, in order to avoid a U.S. bias towards certain non-U.S. journals, the Australian Business Deans Council (ABDC) Journal Ratings List ${ }^{2}$ is utilized to select additional journals. The ABDC is a national council of deans, directors, and department heads of Australian universities, business faculties, and schools. All journals listed as an A or A* (elite) ranking with a code of 1501 (Accounting and Finance) are considered and all U.S. edited journals are eliminated. This results in nine additional journals: Abacus; Accounting and Business Research; Accounting and Finance; Accounting, Auditing, and Accountability Journal; British Accounting Review; Critical Perspectives on Accounting; European Accounting Review; Management Accounting Research; and Contemporary Accounting Research.

\footnotetext{
${ }^{1}$ These rankings are discussed in greater detail in the Data Collection section of this study.

2 The ABDC undertook a full review of its journal ratings list in late 2009. At the time this research was conducted, only the draft list was available. The finalized list of A and A* journals was not significantly different from the draft list, and is available at http://www.abdc.edu.au.
} 
Last, in order to achieve a total of twelve journals to compare with Englebrecht et al. (2008), we review the Journal Quality List $\left(36^{\text {th }}\right.$ edition published $\left.2 / 6 / 10\right)$ as compiled and edited by Professor Anne-Wil Harzing. ${ }^{3}$ The Journal Quality List is a collation of journal rankings from over fifteen sets of rankings from various business school associations, universities, and journals. We specifically search this list for a finance journal, as accountants sometimes publish in premier interdisciplinary publication outlets. We identify European Financial Management as an appropriate journal since it receives an "A" equivalent designation from at least four rankings. Furthermore, professors at U.K. and Irish universities published in European Financial Management at a high rate compared with other non-U.S. finance journals (Beattie and Goodacre, 2012). This journal selection method results in a complete list of twelve journals which are listed in Table 1 and comparable to Englebrecht et al.'s (2008) analysis. ${ }^{4}$

Table 1: Premier Non-U.S. Edited Journals*

\begin{tabular}{l}
\hline Abacus \\
Accounting, Auditing and Accountability Journal \\
Accounting and Business Research \\
Accounting and Finance \\
Accounting Organizations and Society \\
British Accounting Review \\
Contemporary Accounting Research \\
Critical Perspectives on Accounting \\
European Accounting Review \\
European Financial Management \\
Journal of Business Finance and Accounting \\
Management Accounting Research \\
*Compiled from Hull and Wright (1990), the ABDC Journal Ratings List, and the Harzing Journal Quality List and listed \\
alphabetically.
\end{tabular}

\section{Data Collection}

Co-authorship information is collected from these top twelve journals in two-year intervals from 1995 to 2009. The data (i.e., article title, number of pages, accounting specialization, author name, author type, and author affiliation) are obtained from the Ebscohost database. Since the journals only list the authors' affiliated university, our analysis of co--authorship potentially includes multiple departments within universities. Data collected includes all issues of the journal, but does not include supplement issues, conference proceedings, book reviews, notes, comments, obituaries, or any non-scientific contributions. Although several of these articles have academic merit, they are not the types of publications which would be considered by most faculty promotion and tenure committees in evaluation for promotion, tenure, or salary decisions (Ederington, 1979; Englebrecht et al., 2008).

Given the international nature of the journals included in our study, it is difficult to establish an appropriate ranking for the universities included. We choose the 2010 London Financial Times Global MBA Ranking because it is a highly respected financial analysis organization which does include global rankings, as opposed to just U.S. MBA programs. Pursuant to the purposes of this study, we first eliminate all U.S. universities from this list. Next, we select the top 25 remaining universities listed in Table 2 to represent our top tier non-U.S. universities. ${ }^{5}$ Similar to Englebrecht et al. (2008), our analysis of both university rank and researcher's affiliation employs two systematic counting approaches for the treatment of articles published by authors of the same affiliation. First, Counting Method I (CM I) gives credit for one coauthored article to an institute even if they have multiple authors on the same article that is published. For example, the University of Manchester is assigned one credit for an article even if there are three University of Manchester researchers listed as coauthors on that article. Second, Counting Method II (CM II) credits each institution with an article for every coauthor affiliation. Thus, the University of Manchester is assigned three credits for one article if there are three University of Manchester researchers listed as coauthors on that article. For both counting methods, whenever articles are published by researchers at separate institutions,

\footnotetext{
${ }^{3}$ The 37 th edition of this list is available from www.harzing.com.

${ }^{4}$ We note that the inclusion of only one premier non-accounting journal to test $\mathrm{H} 3$ may be a limitation of this paper. However, this journal does provide 196 data points, which is deemed adequate to conduct the logistic analysis for $\mathrm{H} 3$.

${ }^{5}$ Three additional universities were eliminated from our sample as they had no publications in the sample period: the Indian School of Business, Ceibs, and Esade Business School.
} 
credit for one article is given to each organization associated with each author. For instance, if an article is coauthored by a researcher at the London Business School and another researcher at INSEAD, both the London Business School and INSEAD receive credit for a coauthored article.

Table 2: Top Tier Non-U.S. Universities*

\begin{tabular}{llc}
\hline 1. & London Business School & U.K. \\
2. & Insead & France/Singapore \\
3. Instituto De Empresa Business School & Spain \\
4. & Hong Kong University Of Science And Technology & China \\
5. University Of Navarra & Spain \\
6. & Imd & Switzerland \\
7. University Of Oxford & U.K. \\
8. Hec Paris & France \\
9. University Of Cambridge & U.K. \\
10. Lancaster University & U.K. \\
11. Rsm Erasmus University Rotterdam & Netherlands \\
12. Cranfield University & U.K. \\
13. Nanyang Technological University & Singapore \\
14. Chinese University Of Hong Kong & China \\
15. Imperial College London & U.K. \\
16. University Of New South Wales & Australia \\
17. Bocconi University & Italy \\
18. University Of Manchester & U.K. \\
19. City University London & U.K. \\
20. University Of Warwick & U.K. \\
21. University Of Toronto & Canada \\
22. University Of Strathclyde & U.K. \\
23. University Of Western Ontario & Canada \\
24. York University & Canada \\
25. University Of Melbourne & Australia \\
\hline
\end{tabular}

*Compiled from the 2010 London Financial Times Global MBA Ranking.

\section{Development of Logistic Regression Equations}

The logistic regression Equation (1) is estimated for $\mathrm{H} 1$ to evaluate the change in coauthorship among premier non-U.S. edited journals. The dependent variable, CAR, is coded as 0 if the article is sole authored and 1 if it is coauthored. The predictor variable, TIME, denotes the number of two-year time intervals after 1995 in which the article has been published (i.e., $0=1995,1=1997,2=1999,3=2001,4=2003,5=2005,6=2007,7=2009$ ). Additionally, the number of pages of each article is included within each model as a control variable, PAGES.

$$
\ln \frac{P(C A R)}{1-P(C A R)}=b_{0}+b_{1}(T I M E)+b_{2}(P A G E S)+\varepsilon
$$

where

CAR $\quad 1$ if the article was coauthored;

TIME number of two-year time intervals after 1995; and

PAGES number of pages in the article.

To test the model's specification of Hypothesis 2 (H2), logistic regression Equation (2) is estimated by including the journal type (JTYPE) with Equation (1). To test for differences in co-authorship ratios of articles published between selected premier accounting and premier non-accounting journals in our sample, the dummy variable JTYPE is included in the model.

$$
\ln \frac{P(C A R)}{1-P(C A R)}=b_{0}+b_{1}(T I M E)+b_{2}(P A G E S)+b_{3}(J T Y P E)+\varepsilon
$$


where

CAR $\quad 1$ if the article was coauthored;

TIME number of two-year time intervals after 1995;

PAGES number of pages in the article; and

JTYPE $\quad 1$ if the article was published in a premier accounting non-U.S. edited journal and 0 if the article was published in a premier non-accounting non-U.S. edited journal.

Hypothesis $3(\mathrm{H} 3)$ is tested by estimating logistic regression Equation (3). The categorical variable, SPEC, is included in the model to extend Equation (1) and to test whether the specialization area (i.e., Financial, Audit, Managerial, or Other) impacts the co-authorship ratio ${ }^{6}$. The baseline for Equation (3) represents Financial articles because they constitute the largest portion of our sample, $55.50 \%$ (Table 6).

where

$$
\begin{aligned}
\ln \frac{P(C A R)}{1-P(C A R)}= & b_{0}+b_{1}(T I M E)+b_{2}(P A G E S)+b_{3}(S P E C-A U D)+ \\
& b_{4}(S P E C-M A N)+b_{5}(S P E C-O T H)+\varepsilon
\end{aligned}
$$
CAR
1 if the article was coauthored;
TIME number of two-year time intervals after 1995;
PAGES number of pages in the article;
SPEC-AUD $\quad 1$ if the article was within the Audit specialization;
SPEC-MAN 1 if the article was within the Managerial specialization;
SPEC-OTH $\quad 1$ if the article was not within the Financial, Audit, or Managerial specialization areas.

To test the model specification of Hypothesis 4 (H4), logistic regression Equation (4) is estimated by including the dummy variable RANK to expand logistic regression Equation (1). RANK is coded as one to indicate a Top 25 non-U.S. institution. For the purpose of this equation, all U.S. academic and non-academic researchers are eliminated. Logistic equation (4) is tested for both CM I and CM II.

$$
\ln \frac{P(C A R)}{1-P(C A R)}=b_{0}+b_{1}(T I M E)+b_{2}(P A G E S)+b_{3}(R A N K)+\varepsilon
$$

where

CAR $\quad 1$ if the article was coauthored;

TIME number of two-year time intervals after 1995;

PAGES number of pages in the article; and

RANK $\quad 1$ if the author's affiliated university is ranked among the top 25 non-U.S. academic institutions.

Last, the logistic regression Equation (5) is estimated for H5 and includes a baseline of articles published by researchers at non-U.S. universities. The dichotomous variable, U.S., indicates that the article is written by a researcher affiliated with a U.S. university. As with Equation (4), logistic Equation (5) investigates both CM I and CM II, but does not eliminate U.S. academic.

$$
\ln \frac{P(C A R)}{1-P(C A R)}=b_{0}+b_{1}(T I M E)+b_{2}(P A G E S)+b_{3}(U S)+\varepsilon
$$

where

CAR $\quad 1$ if the article was coauthored;

TIME number of two-year time intervals after 1995;

PAGES number of pages in the article; and

US $\quad 1$ if a U.S. academic researcher;

\footnotetext{
${ }^{6}$ Because only $1.45 \%$ articles surveyed in our sample are from Taxation area, we group tax articles in the Other area. 


\section{RESULTS AND ANALYSIS}

\section{Aggregated Co-authorship Trends}

The total sample includes 2,553 articles representing 4,976 author contributions affiliated with 942 different academic institutions. Consistent with the results in Englebrecht et al. (2008) indicating an increase in coauthorship, Table 3 Panel A reports that the ratio of single authored manuscripts declined by 11.72 percent between 1995 and 2009. Conversely, during the same period, the proportion of papers with two, three, and four or more authors increased 2.08, 8.13, and 1.51 percent, respectively. Furthermore, the increase of articles with four or more authors is an indication that the motivations for co-authorship are great enough for researchers to seek out multiple colleagues.

Panel B of Table 3 reports a fairly consistent increase, 1.83 to 2.07 , in the average number of authors during the study period. This result is similar to that of Beattie and Goodacre (2004), and indicates a continued increase in the average number of authors per publication during the study period of 0.034 per year. The table displays abnormal increases in coauthors per article in 2005 and 2007 with increases of 0.15 and 0.19 , respectively. However, the co-authorship ratio appears to adjust back to normal in 2009 which experienced a 0.14 decrease.

\section{Aggregate Co-authorship Ratio}

As shown in Table 4, the coefficients of the control variable PAGES are positive and significant (p-value $\leq$ 0.0044) for all models, signifying that there is a strong positive correlation between the number of pages per article and the number of co-authorship. Additionally, in Table 4, the coefficient of TIME is positive and significant (pvalue < 0.0001) for Model 1 while holding PAGES constant, thus rejecting H1. Moreover, the coefficients for TIME are significant and positive for all models analyzed. These results are consistent with the widely held belief that the aggregate co-authorship ratio has been increasing and that the length of articles is greater when papers are coauthored (Hamermesh and Oster, 2002; Beattie and Goodacre, 2004; Swanson, 2004; Acedo et al., 2006; Englebrecht et al., 2008). The results suggest that single-authored and shorter papers are less likely to be published in the elite accounting and finance journals now than previously.

\section{Co-authorship by Journal Type}

The results from Model 2 (Table 4) indicate that co-authorship ratios for premier non-U.S. edited accounting journals are significantly lower than those of the premier non-U.S. edited non-accounting journals analyzed $(\mathrm{p}=0.0288)$ while holding TIME and PAGES constant. Figure 1 graphically depicts the growth trend which is the result of a significant TIME coefficient as previously identified in Table 4. This outcome is similar to that found by Englebrecht et al. (2008) and Swanson (2004). Specifically, co-authorship ratios are higher among non-accounting journals. Table 5 and Figures 1 and 2 further confirm the differences of co-authorship between accounting and non-accounting journals.

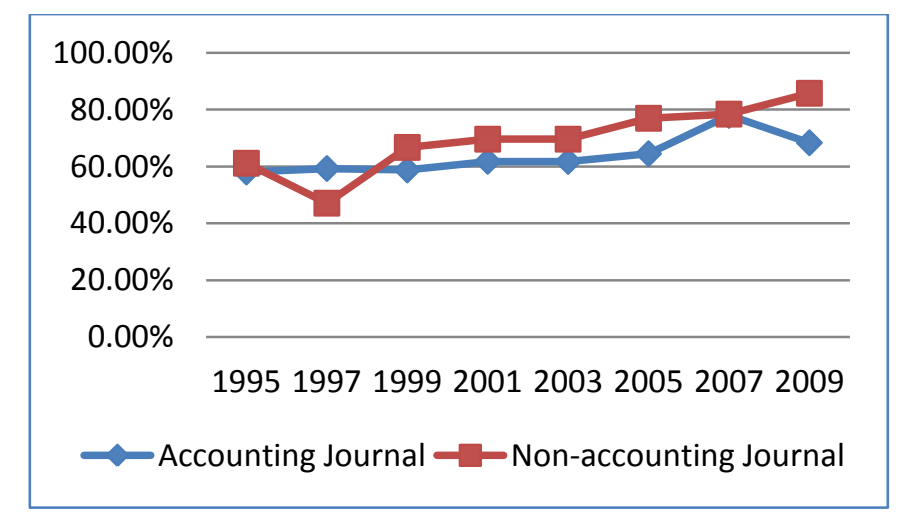

Figure 1: Incidence of Coauthorship by Journal Category (by Year) 
Table 3: Descriptive Statistics

\begin{tabular}{|c|c|c|c|c|c|c|c|c|c|}
\hline \multicolumn{10}{|c|}{ Panel A: Portion of Single and Coauthored papers } \\
\hline Number of Authors & 1995 & 1997 & 1999 & 2001 & 2003 & 2005 & 2007 & 2009 & Total \\
\hline One & $41.61 \%$ & $41.56 \%$ & $40.80 \%$ & $37.20 \%$ & $37.67 \%$ & $34.59 \%$ & $21.81 \%$ & $29.89 \%$ & $35.21 \%$ \\
\hline Two & $35.91 \%$ & $37.01 \%$ & $36.45 \%$ & $41.30 \%$ & $39.00 \%$ & $35.17 \%$ & $42.78 \%$ & $37.99 \%$ & $38.23 \%$ \\
\hline Three & $19.80 \%$ & $18.51 \%$ & $18.73 \%$ & $18.43 \%$ & $21.33 \%$ & $25.00 \%$ & $28.05 \%$ & $27.93 \%$ & $22.52 \%$ \\
\hline Four or More & $2.68 \%$ & $2.92 \%$ & $4.02 \%$ & $3.07 \%$ & $2.00 \%$ & $5.24 \%$ & $7.36 \%$ & $4.19 \%$ & $4.04 \%$ \\
\hline Coauthorship Ratio & $58.39 \%$ & $58.44 \%$ & $59.20 \%$ & $62.80 \%$ & $62.33 \%$ & $65.41 \%$ & $78.19 \%$ & $70.11 \%$ & $64.79 \%$ \\
\hline Total Number of Papers & 298 & 308 & 299 & 293 & 300 & 344 & 353 & 358 & 2553 \\
\hline \multicolumn{10}{|c|}{ Panel B: Coauthors per Article } \\
\hline \multicolumn{10}{|l|}{ Current study } \\
\hline Accounting only & 1.83 & 1.84 & 1.86 & 1.88 & 1.86 & 2.00 & 2.21 & 2.06 & 1.95 \\
\hline Total & 1.83 & 1.83 & 1.86 & 1.88 & 1.87 & 2.02 & 2.21 & 2.07 & 1.95 \\
\hline
\end{tabular}

Table 4: Logistic Regression Results Coefficient Estimate (Probability Level)

\begin{tabular}{|c|c|c|c|c|c|c|c|}
\hline Variable & Model 1 & Model 2 & Model 3 & $\begin{array}{c}\text { CM I } \\
\text { Model } 4\end{array}$ & $\begin{array}{c}\text { CM II } \\
\text { Model } 4\end{array}$ & $\begin{array}{c}\text { CM I } \\
\text { Model } 5\end{array}$ & $\begin{array}{c}\text { CM II } \\
\text { Model } 5\end{array}$ \\
\hline INTERCEPT & $\begin{array}{l}-0.2104 \\
(0.1133)\end{array}$ & $\begin{array}{c}0.1263 \\
(0.5350)\end{array}$ & $\begin{array}{c}-0.0584 \\
(0.6734)\end{array}$ & $\begin{array}{c}0.2027 \\
(0.1569)\end{array}$ & $\begin{array}{c}0.5939 \\
(<.0001)\end{array}$ & $\begin{array}{c}0.1938 \\
(0.1253)\end{array}$ & $\begin{array}{c}0.5707 \\
(<.0001)\end{array}$ \\
\hline TIME & $\begin{array}{c}0.0894 \\
(<.0001)\end{array}$ & $\begin{array}{c}0.0871 \\
(<.0001)\end{array}$ & $\begin{array}{c}0.0890 \\
(<.0001)\end{array}$ & $\begin{array}{c}0.1279 \\
(<.0001)\end{array}$ & $\begin{array}{c}0.1215 \\
(<.0001)\end{array}$ & $\begin{array}{c}0.1048 \\
(<.0001)\end{array}$ & $\begin{array}{c}0.0995 \\
(<.0001)\end{array}$ \\
\hline PAGES & $\begin{array}{c}0.0217 \\
(<.0001)\end{array}$ & $\begin{array}{c}0.0222 \\
(<.0001)\end{array}$ & $\begin{array}{c}0.0220 \\
(<.0001)\end{array}$ & $\begin{array}{c}0.0187 \\
(0.0012)\end{array}$ & $\begin{array}{c}0.0161 \\
(0.0044)\end{array}$ & $\begin{array}{c}0.0231 \\
(<.0001)\end{array}$ & $\begin{array}{c}0.0209 \\
(<.0001)\end{array}$ \\
\hline JTYPE & & $\begin{array}{l}-0.3661 \\
(0.0288)\end{array}$ & & & & & \\
\hline SPEC_AUD & & & $\begin{array}{l}-0.1320 \\
(0.3282)\end{array}$ & & & & \\
\hline SPEC_MAN & & & $\begin{array}{l}-0.2607 \\
(0.0228)\end{array}$ & & & & \\
\hline SPEC_OTH & & & $\begin{array}{l}-0.5919 \\
(<.0001)\end{array}$ & & & & \\
\hline RANK & & & & $\begin{array}{c}0.0733 \\
(0.5294)\end{array}$ & $\begin{array}{c}0.0595 \\
(0.5972)\end{array}$ & & \\
\hline US & & & & & & $\begin{array}{c}0.5621 \\
(<.0001)\end{array}$ & $\begin{array}{c}0.4584 \\
(<.0001)\end{array}$ \\
\hline $\begin{array}{l}\text { No. of Observations } \\
\text { Hosmer-Lemeshow }\end{array}$ & $\begin{array}{c}2553 \\
14.493(0.0698)\end{array}$ & $\begin{array}{c}2553 \\
13.770 \\
(0.0880)\end{array}$ & $\begin{array}{c}2553 \\
8.351 \\
(0.3999)\end{array}$ & $\begin{array}{c}2844 \\
12.643 \\
(0.1248)\end{array}$ & $\begin{array}{c}3593 \\
10.855 \\
(0.2101)\end{array}$ & $\begin{array}{c}3858 \\
4.221 \\
(0.8367)\end{array}$ & $\begin{array}{c}4804 \\
11.721 \\
(0.1641)\end{array}$ \\
\hline
\end{tabular}


Table 5: Co-authorship Ratios by Journal

\begin{tabular}{|c|c|c|c|c|c|c|c|c|c|}
\hline Journal Type/Name & Journal & 1995 & 1997 & 1999 & 2001 & 2003 & 2005 & 2007 & 2009 \\
\hline \multirow{2}{*}{\multicolumn{10}{|c|}{$\begin{array}{r}\text { Accounting Journals } \\
\text { Accounting, Auditing and }\end{array}$}} \\
\hline & & & & & & & & & \\
\hline Accountability Journal & AAA $\mathbf{A J}$ & $50.00 \%$ & $57.14 \%$ & $43.48 \%$ & $62.50 \%$ & $46.88 \%$ & $46.88 \%$ & $87.50 \%$ & $61.90 \%$ \\
\hline Abacus & ABACUS & $50.00 \%$ & $72.73 \%$ & $58.82 \%$ & $58.82 \%$ & $42.11 \%$ & $56.25 \%$ & $65.00 \%$ & $66.67 \%$ \\
\hline Accounting and Business Research & ABR & $77.27 \%$ & $45.45 \%$ & $72.73 \%$ & $83.33 \%$ & $82.35 \%$ & $62.50 \%$ & $85.71 \%$ & $72.73 \%$ \\
\hline Accounting and Finance & $\mathbf{A F}$ & $50.00 \%$ & $55.56 \%$ & $66.67 \%$ & $75.00 \%$ & $76.47 \%$ & $80.65 \%$ & $86.96 \%$ & $90.00 \%$ \\
\hline \multicolumn{10}{|l|}{ Accounting Organizations and } \\
\hline Society & AOS & $58.06 \%$ & $57.89 \%$ & $61.29 \%$ & $60.00 \%$ & $44.44 \%$ & $58.62 \%$ & $78.57 \%$ & $52.17 \%$ \\
\hline British Accounting Review & BAR & $21.43 \%$ & $64.71 \%$ & $38.10 \%$ & $66.67 \%$ & $53.85 \%$ & $60.00 \%$ & $77.78 \%$ & $80.00 \%$ \\
\hline \multicolumn{10}{|l|}{ Contemporary Accounting } \\
\hline $\begin{array}{l}\text { Research } \\
\text { Critical Perspectives on }\end{array}$ & CAR & $68.18 \%$ & $77.27 \%$ & $62.50 \%$ & $63.64 \%$ & $70.83 \%$ & $73.33 \%$ & $83.33 \%$ & $76.47 \%$ \\
\hline Accounting & CPA & $47.83 \%$ & $37.93 \%$ & $36.36 \%$ & $47.22 \%$ & $50.00 \%$ & $44.19 \%$ & $69.23 \%$ & $61.70 \%$ \\
\hline European Accounting Review & EAR & $34.48 \%$ & $48.15 \%$ & $61.76 \%$ & $62.50 \%$ & $62.07 \%$ & $60.71 \%$ & $68.00 \%$ & $83.33 \%$ \\
\hline $\begin{array}{l}\text { Management Accounting Research } \\
\text { Journal of Business Finance and }\end{array}$ & \multicolumn{8}{|c|}{ Journal of Business Finance and } & $50.00 \%$ \\
\hline Accounting & JBFA & $72.86 \%$ & $73.13 \%$ & $71.74 \%$ & $75.56 \%$ & $78.72 \%$ & $81.67 \%$ & $78.46 \%$ & $80.85 \%$ \\
\hline & Subtotal & $58.21 \%$ & $59.11 \%$ & $58.72 \%$ & $62.22 \%$ & $61.73 \%$ & $64.47 \%$ & $77.92 \%$ & $68.42 \%$ \\
\hline $\begin{array}{l}\text { Non-accounting Journal } \\
\text { European Financial Management }\end{array}$ & & & & & & & & & \\
\hline $\begin{array}{l}\text { European Financial Management } \\
\text { Total }\end{array}$ & EFM & $\begin{array}{l}61.11 \% \\
58.39 \%\end{array}$ & $\begin{array}{l}47.06 \% \\
58.44 \%\end{array}$ & $\begin{array}{l}66.67 \% \\
59.20 \%\end{array}$ & $\begin{array}{l}69.57 \% \\
62.80 \%\end{array}$ & $\begin{array}{l}69.57 \% \\
62.33 \%\end{array}$ & $\begin{array}{l}76.92 \% \\
65.41 \% \\
\end{array}$ & $\begin{array}{l}80.56 \% \\
78.19 \%\end{array}$ & $\begin{array}{l}85.71 \% \\
70.11 \%\end{array}$ \\
\hline
\end{tabular}

\section{Co-authorship by Accounting Specialization}

Accounting has four primary areas of specializations from which researchers choose to publish. The primary areas include financial accounting, auditing, managerial accounting, and taxation. The division of labor hypothesis suggests that highly specialized areas of accounting will necessitate higher levels of co-authorship (Barnett $e t$ al, 1988). Table 6 analyzes the ratio of papers by accounting specialization and indicates a higher rate among financial accounting researchers, 55.50 percent, than that of the researchers from the other areas, on average 14.83 percent, which may lend credence to the division of labor hypothesis. Model 3 from Table 4 confirms the relatively high financial accounting co-authorship ratio with negative coefficients for each of the other areas studied. However, only the managerial accounting and the "other" areas of accounting categories are significantly different when holding PAGES constant over TIME, with p-values 0.0228 and less than 0.0001 , respectively. Therefore, H3 is rejected indicating a significant difference in co-authorship amongst areas of accounting specialization. Specifically, managerial articles and articles from "other" category are less likely to be coauthored than financial and auditing articles.

\section{Co-authorship by University Rank}

Table 7 provides a listing of the top ten non-U.S. most productive universities in our journal sample considering both Counting Method I (CMI) and Counting Method II (CMII). Some prior research provides empirical evidence that co-authorship is higher among researchers at top tier and doctoral granting institutions compared with researchers at lower tier and non-doctoral granting institutions (Englebrecht et al., 1994; Sutter and Kocher, 2004). Our results for Model 4 (Table 4) indicate that the co-authorship ratio for the Top 25 non-U.S. universities is not significantly different from that of non-Top 25 non-U.S. universities included in our study $(\mathrm{p}=$ 0.5294 and 0.5972 for CMI and CMII, respectively). These conclusions for co-authorship by university rank are robust in that they are consistent for both CMI and CMII. These results are similar to Englebrecht et al.'s (2008) findings which do not reveal significant differences in co-authorship ratio among universities ranked in their study. Englebrecht et al. (2008) indicate that while the result may appear surprising, nonetheless, it is consistent with the Hansen (1991) argument that consistency in co-authorship ratios is caused by graduates of upper-tier graduate schools being hired by lower-tier institutions which in turn reduces the differences between them. 


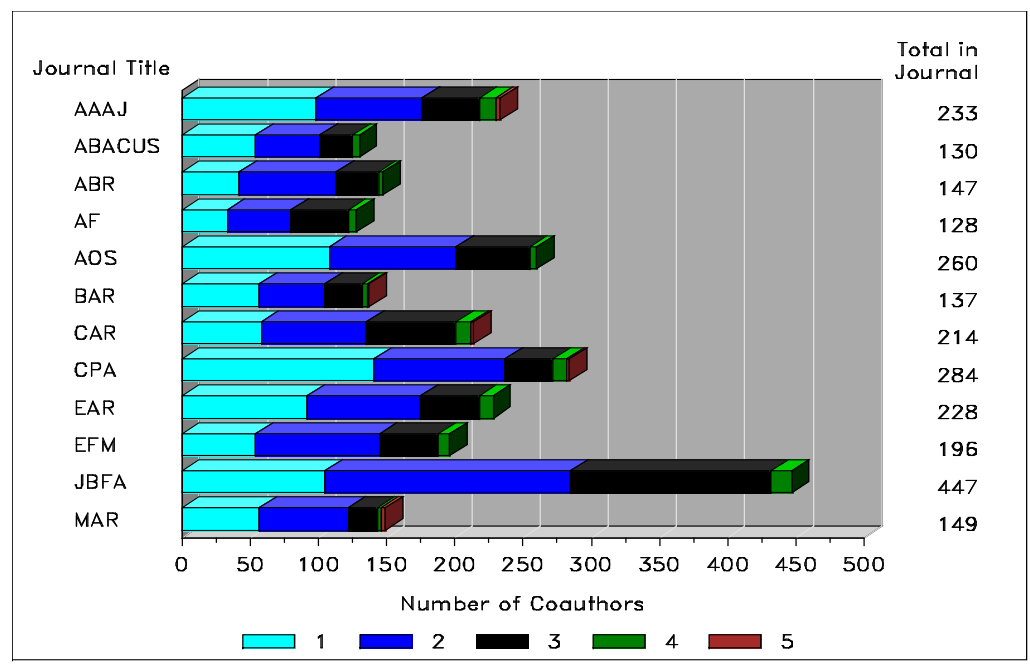

Figure 2: Distribution of Coauthorship

Table 6: Portion of Papers in Each Accounting Area (by Year)

\begin{tabular}{|c|c|c|c|c|c|c|c|c|c|}
\hline Area & 1995 & 1997 & 1999 & 2001 & 2003 & 2005 & 2007 & 2009 & Total \\
\hline AUD & $7.72 \%$ & $13.64 \%$ & $13.71 \%$ & $16.38 \%$ & $12.00 \%$ & $9.30 \%$ & $12.46 \%$ & $9.78 \%$ & $11.79 \%$ \\
\hline FIN & $62.08 \%$ & $49.68 \%$ & $51.51 \%$ & $52.22 \%$ & $58.00 \%$ & $56.69 \%$ & $57.23 \%$ & $56.14 \%$ & $55.50 \%$ \\
\hline MAN & $17.11 \%$ & $15.58 \%$ & $17.39 \%$ & $18.43 \%$ & $17.33 \%$ & $18.31 \%$ & $17.00 \%$ & $18.44 \%$ & $17.47 \%$ \\
\hline ОTH & $13.09 \%$ & $21.10 \%$ & $17.39 \%$ & $12.97 \%$ & $12.67 \%$ & $15.70 \%$ & $13.31 \%$ & $15.64 \%$ & $15.24 \%$ \\
\hline Total Number of Papers & 298 & 308 & 299 & 293 & 300 & 344 & 353 & 358 & 2553 \\
\hline
\end{tabular}

\section{Coauthorship Comparing International with Other Researchers}

Beattie and Goodacre (2004) and Prather-Kinsey and Rueschhoff (2004) indicate that co-authorship among non-U.S. researchers is increasing, but the rate remains less than that of U.S. researchers. Our results in Model 5 (Table 4) are consistent with the prior research indicating a significantly higher U.S. co-authorship ratio (coefficients $\geq 0.4580$ and p-values < 0.0001 for CMI and CMII) compared with non-U.S. co-authorship ratios, rejecting H5. Figure 3 also provides a graphical analysis of these results by year. However, there is no significant difference in co-authorship ratios between non-U.S. academic researchers and non-academic researchers ( $\mathrm{p}$-values $\geq 0.5852$ for CMI and CMII). ${ }^{7}$ Our results for co-authorship comparing academic international researchers with other researchers in the study are robust in that they are consistent for both CMI and CMII. These results are inconsistent with and only partially comparable to Englebrecht et al.'s (2008) results. Englebrecht et al. (2008) do not observe a significant difference between co-authorship ratios of U.S. and international academic researchers. However, Englebrecht et al. (2008) observe a significant difference between U.S. academic and non-academic researchers, a comparison which is not tested in our study as our baseline for the model is non-U.S. academic researchers.

\footnotetext{
${ }^{7} 172$ authors are non-academic researchers (3.46\%) and 1,211 authors are U.S. researchers (24.34\%). 
Table 7: Top 10 Universities by Productivity*

\begin{tabular}{|c|c|c|}
\hline \multirow{2}{*}{ Universities } & \multicolumn{2}{|c|}{ Method of Coauthored Credits } \\
\hline & CMI & CMII \\
\hline 1. University Of Manchester & 89 & 114 \\
\hline 2. Cardiff University & 66 & 103 \\
\hline 3. University Of Sydney & 65 & 92 \\
\hline 4. University Of New South Wales & 57 & 80 \\
\hline 5. Lancaster University & 39 & 60 \\
\hline 6. Monash University & 42 & 59 \\
\hline 7. University Of Edinburgh & 51 & 57 \\
\hline 8. University Of Strathclyde & 40 & 50 \\
\hline 9. University Of London & 38 & 47 \\
\hline 10. University Of Dundee & 30 & 46 \\
\hline
\end{tabular}

*Excludes U.S. universities.

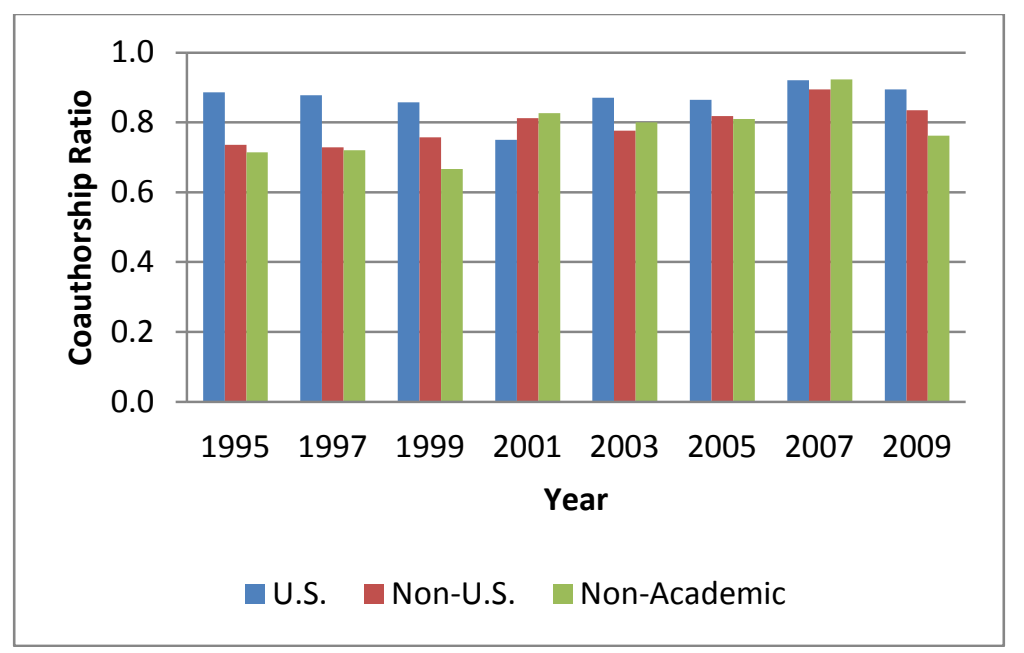

Figure 3: Coauthorship Ratios by Author's Affiliation Type

\section{CONCLUSIONS, LIMITATIONS, AND FUTURE RESEARCH}

Generally, scholars agree that the coauthorship level has increased over the past thirty years and that the length of articles is greater when papers are coauthored. To gain further insight into the level of co-authorship, we examine the co-authorship ratio among premier non-U.S. edited accounting and finance journals over the fifteen year period from 1995 to 2009. Our results suggest that for the years considered, the aggregate co-authorship ratio has increased significantly. Furthermore, the co-authorship ratio for premier non-U.S. accounting journals is less than that of premier non-U.S. non-accounting journals. When considering accounting specializations, our results indicate that financial accounting has the highest level of co-authorship and managerial accounting and the "other" classification are significantly lower than financial accounting with respect to article length. Additionally, we provide an analysis of co-authorship comparing the Top 25 non-U.S. universities with the remaining non-U.S. academic institutions in our study and find that the co-authorship ratio is not significantly different between the two groups. Our final co-authorship ratio comparisons are between non-U.S and U.S. researchers and non-U.S. and nonacademic researchers. The study concludes that co-authorship among non-U.S. researchers is significantly lower than co-authorship among U.S. researchers, and co-authorship is not significantly different between non-U.S. researchers and non-academic researchers.

This study contributes to the literature on publication trends in academic accounting research in several ways. First, since the Association to Advance Collegiate Schools of Business International (AACSB) is a multinational organization, publication trends around the world may be compared to assess world-wide developments. Specifically, we investigate the co-authorship ratio in twelve premier non-U.S. edited accounting and finance journals and find that the co-authorship trend around the world is similar to that of Englebrecht et al. (2008) 
in the U.S. (i.e., co-authorship is increasing). Second, although the world-wide growth in co-authorship is similar, non-U.S. edited premier accounting and finance journals have a lower incidence of co-authorship. These results provide some evidence that the acceptability of coauthored manuscripts for tenure and promotion decisions may differ for non-U.S. academic institution as compared with U.S. academic institutions. Consequently, our findings add to the knowledge surrounding publication trends for academics as assessed by department chairpersons and universities around the world in determining quality research. Last, researchers can use the results of this study to demonstrate that co-authorship is becoming increasingly necessary in all journals (not just U.S. edited publications). Therefore, administrators and tenure committees should place more weight on the academic contribution of coauthored articles in non-U.S. edited journals as indicated by the current trend. In contrast to simply disregarding articles which are not sole authored, researchers can use our results to advocate that all papers should be scrutinized based on other measures of quality, such as the number of citations, rather than just the number of authors per manuscript.

\section{Limitations}

There are a few limitations to our results. First, since we use the 2010 London Financial Times Global MBA Ranking, our study could be limited due to this choice of rankings. There is no ideal ranking for non-U.S. universities; therefore, there may be bias in any ranking. Additionally, research has demonstrated the prevalence of U.K. universities among European countries (Chan et al., 2006). Second, our premier journals are not of comparable quality to those used by Englebrecht et al. (2008). Overall, considering various sources, the non-U.S. journals in this study are less highly ranked. This difference may account for some of the inconsistent results obtained when comparing the results to previous studies. Third, this study only includes one non-accounting journal which may not adequately represent the population of non-accounting non-U.S. edited journals. However, the outcome of the analysis using one non-accounting journal is consistent with that of the previous research.

\section{Extensions}

The current study and prior research confirm that the co-authorship ratio is not only increasing among U.S. accounting researchers, but also among accounting researchers internationally. However, research opportunities are available to ascertain whether this phenomenon is present in highly rated non-premier accounting and finance journals. It may be that space in premier accounting and finance journals is so limited that co-authorship is required for faculty to satisfy promotion and tenure requirements. Further, there may be a larger percentage of non-academic researchers, who have been shown to coauthor less frequently, publishing in these non-premier journals that may result in a reduction of the overall co-authorship level.

Another area of potential research concerns relationships among coauthors. Specifically, are accounting academic coauthors associated with each other via their doctoral granting institution, their current or previous institution(s) of employment, or some other means? The answer to this question begins to refine the explanation of the cause(s) of the increase in the co-authorship level among accounting researchers as researchers develop strategic alliances to enhance publication productivity.

\section{AUTHOR INFORMATION}

Ted D. Englebrecht, Ph.D., Smolinski Eminent Scholar Chair, School of Accountancy, College of Business, Louisiana Tech University. E-mail: TEnglebr@cab.latech.edu (Corresponding author)

Xiaoyan Chu, DBA, Assistant Professor, Department of Accounting, College of Business, Nicholls State University. E-mail: xiaoyan.chu@nicholls.edu

Fred Coleman, Doctoral Candidate, School of Accountancy, College of Business, Louisiana Tech University. E-mail: flc005@latech.edu

Rebecca Martin, DBA, School of Accountancy, College of Business, Louisiana Tech University. E-mail: rbm012@latech.edu

1090 Copyright by author(s) $\underline{\text { Creative Commons License CC-BY }}$

2013 The Clute Institute 


\section{REFERENCES}

1. Acedo, F.J., C. Barroso, C. Casanueva, and J. L. Galan. 2006. Co-authorship in Management and Organizational Studies: An Empirical and Network Analysis. Journal of Management Studies (Vol. 43) 957-983.

2. Attaway, A., S. Baxendale, B. Foster, and J. Karcher. 2008. Reassessing Accounting Faculty Scholarly Expectations: Journal Classification by Author Affiliation. Academy of Educational Leadership Journal (Vol. 12) 71-86.

3. Ballas, A. and V. Theoharakis. 2003. Exploring Diversity in Accounting through Faculty Journal Perceptions. Contemporary Accounting Research (Vol. 20) 619-644.

4. Barnett, A. H., R. W. Ault, and D. L. Kaserman. 1988. The Rising Incidence of Co-authorship in Economics: Further Evidence. The Review of Economics and Statistics (Vol. 70) 539-543.

5. Beattie, V., and A. Goodacre. 2004. Publishing Patterns within the U.K. Accounting and Finance Academic Community. The British Accounting Review (Vol. 36) 7-44.

6. Beattie, V., and A. Goodacre. 2012. Publishing Records of Accounting and Finance Faculty Promoted to Professor: Evidence from the UK. Accounting and Business Research (Vol. 42) 197-231.

7. Brown, L. D. and R. J. Huefner. 1994. The Familiarity with and Perceived Quality of Accounting Journals: Views of Senior Accounting Faculty in Leading U.S. MBA Programs. Contemporary Accounting Research (Vol. 11) 223-250.

8. Buchheit, S. D. Collins, and A. Reitenga. 2002. A Cross-Discipline Comparison of Top-Tier Academic Journal Publication Rates: 1997-1999. Journal of Accounting Education (Vol. 20) 123-130.

9. Campbell, D. R., J. Gaertner, and R. P. Vecchio. 1983. Perceptions of Promotion and Tenure Criteria: A Survey of Accounting Educators. Journal of Accounting Education (Vol. 1) 83-92.

10. Cargile, B. R., and B. Bublitz. 1986. Factors Contributing to Published Research by Accounting Faculties. The Accounting Review (Vol. 61) 158-178.

11. Chen, Y., A. Gupta, and L. Hoshower. 2006. Factors That Motivate Business Faculty to Conduct Research: An Expectancy Theory Analysis. Journal of Education for Business (Vol. 81) 179-189.

12. Chen, Y., M. Nixon, A. Gupta, and L. Hoshower. 2010. Research Productivity of Accounting Faculty: An Exploratory Study. American Journal of Business Education (Vol. 3) 101-115.

13. Chung, K. H., H. S. Pak, and R. A. K. Cox. 2005. Patterns of Research Output in the Accounting Literature: A Study of the Bibliometric Distributions. Abacus (Vol. 28) 168-185.

14. Ederington, L. H. 1979. Aspects of the Production of Significant Financial Research. The Journal of Finance (Vol. 34) 777-786.

15. Englebrecht, T. D., S. A. Hanke, and Y. Kuang. 2008. An Assessment of Patterns of Co-authorship for Academic Accountants within Premier Journals: Evidence from 1979-2004. Advances in Accounting (Vol. 24) $172-181$.

16. Englebrecht, T. D., G. S. Iyer, and D. M. Patterson. 1994. An Empirical Investigation of the Publication Productivity of Promoted Accounting Faculty. Accounting Horizons (Vol. 8) 45-68.

17. Hamermesh, D. S., and M. S. Oster. 2002. Tools or Toys? The Impact of High Technology on Scholarly Productivity. Economic Inquiry (Vol. 40) 539-555.

18. Hansen, W. L. 1991. The Education and Training of Economics Doctorates: Major Findings of the Executive Secretary of the American Economic Association's Commission on Graduate Education in Economics. Journal of Economic Literature (Vol. 23) 1054-1087.

19. Hasselback, J. R., A. Reinstein, and E. S. Schwan. 2000. Benchmarks for Evaluating the Research Productivity of Accounting Faculty. Journal of Accounting Education (Vol. 18) 79-97.

20. Henry, W. R., and E. E. Burch. 1974. Institutional Contributions to Scholarly Journals of Business. Journal of Business (Vol. 47) 56-66.

21. Herron, T. L., and Hall, T. W. 2004. Faculty Perceptions of Journals: Quality and Publishing Feasibility. Journal of Accounting Education (Vol. 22) 175-210.

22. Hull, R. P., and G. B. Wright. 1990. Faculty Perceptions of Journal Quality: An Update. Accounting Horizons (Vol. 4) 77-98.

23. Hyndman, N., hÓgartaigh C. Ó., and K. Warnock. 2006. Patterns of Publication in Academic Accounting: Contours of a Changing Landscape in the Irish University Sector. The Irish Accounting Review (Vol. 13) 45-64. 
24. Jones, J. J. and R. Roberts. 2005. International Publishing Patterns: An Investigation of Leading U.K. and U.S. Accounting and Finance Journals. Journal of Business Finance \& Accounting (Vol. 32) 1107-1140.

25. Levitan, A. S., and R. Ray. 1992. Personal and Institutional Characteristics Affecting Research Productivity of Academic Accountants. Journal of Education for Business (Vol. 67) 335-341.

26. Lowe, A., and Locke, J. 2002. Problematising the Construction of Journal Quality: An Engagement with the Mainstream. Accounting Forum (Vol. 26) 45-71.

27. Pollard, W. and R. Copeland. 1985. Evaluating the Robustness of Multivariate Tax Models to Errors: A Section 162(a)(2) Illustration. Journal of the American Taxation Association (Vol. 7) 7-18.

28. Prather-Kinsey, J. J. and N. G. Rueschhoff. 2004. An Analysis of International Accounting Research in U.S.- and Non-U.S.-based Academic Accounting Journals. Journal of International Research (Vol. 3) 6381.

29. Reeve, R. C. and P. J. Hutchison. 1988. The Contribution of Non-U.S. Institutions to Academic Accounting Journals. Abacus 90-94.

30. Reinstein, A. and T. G. Calderon. 2006. Examining Accounting Departments' Rankings of the Quality of Accounting Journals. Critical Perspectives on Accounting (Vol. 17) 457-490.

31. Rutledge, R., and K. Karim. 2009. Determinants of Co-authorship for the Most Productive Authors of Accounting Literature. Journal of Education for Business (Vol. 84) 130-134.

32. Schultz, J. J., J. A. Meade, and I. Khurana. 1989. Changing Roles of Teaching, Research, and Service in the Promotion and Tenure Decisions for Accounting Faculty. Issues in Accounting Education (Vol. 4) $109-119$.

33. Street, D. L., and C. P. Baril. 1994. Scholarly Accomplishments in Promotion and Tenure Decisions of Accounting Faculty. Journal of Accounting Education (Vol. 12) 121-139.

34. Street, D. L., C. P. Baril, and R. L. Benke, Jr. 1993. Research, Teaching, and Service in Promotion and Tenure Decisions of Accounting Faculty. Journal of Accounting Education (Vol. 11) 43-60.

35. Swanson, E. P. 2004. Publishing in the Majors: A Comparison of Accounting, Finance, Management, and Marketing. Contemporary Accounting Research (Vol. 21) 223-255.

36. Valacich, J. S., A. Fuller, M. A. Mark, C. Schneider, and A. R. Dennis. 2006. Issues and Opinions: Publication Opportunities in Premier Business Outlets: How Level Is the Playing Field? Information Systems Research (Vol. 17) 107-125.

37. Yunker, J. A. 2000. Doing Things the Hard Way--Problems with Mission-Inked AACSB Accreditation Standards and Suggestions for Improvement. Journal of Education for Business (Vol. 75) 348-353.

38. Zeff, S. A. 1996. A Study of Academic Research Journals in Accounting. Accounting Horizons (Vol. 10) $158-177$. 